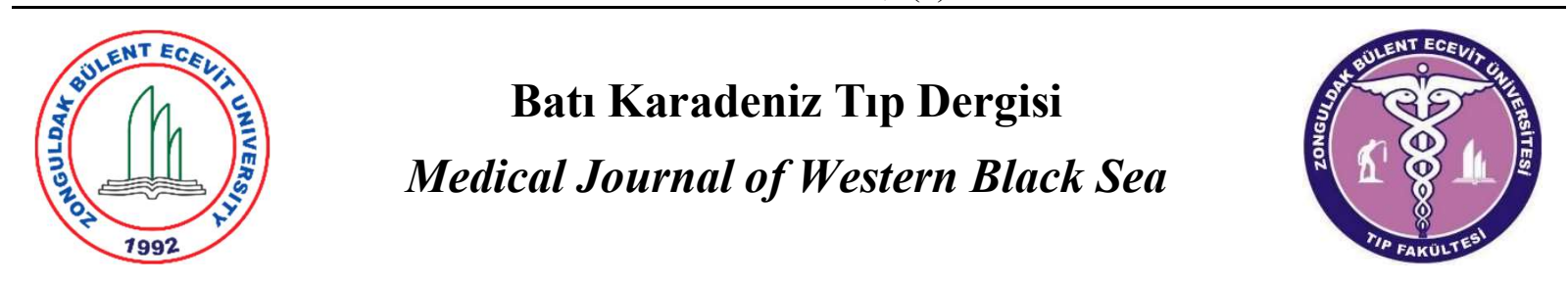

Araştırma Makalesi

Doi: 10.29058/mjwbs.2019.3.4

\title{
Çevresel Zenginleștirme Bilateral Karotid Arter Oklüzyonu ile Oluşan Retinal Oksidatif Stresi Azaltır
}

İncı Turan a , Osman Cengıl b, Büşra Onar ${ }^{\text {b }}$, Birgül Altuğ ${ }^{\text {b }}$, Hale Sayan Ozacmak ${ }^{\text {a }}$, Veysel Haktan Ozacmak ${ }^{a}$

${ }^{a}$ Zonguldak Bülent Ecevit Üniversitesi, Tıp Fakültesi, Fizyoloji Anabilim Dalı, Zonguldak, Türkiye.

${ }^{b}$ Zonguldak Bülent Ecevit Üniversitesi Sağlık Bilimleri Enstitüsü Fizyoloji Anabilim Dalı, Zonguldak, Türkiye.

ORCID : Inc1 Turan 000000032211 3914, Osman Ceng1l 000000020702 6751, Busra Onar 000000034772 8069, Birgul Altug 000000024193 4219, Hale Sayan Ozacmak 000000023564 0468, Veysel Haktan Ozacmak 0000000326518353

\begin{tabular}{l}
\hline M A K A L E \\
B İ L G I S İ \\
\hline Gönderilme Tarihi: \\
22.11 .2019 \\
Revizyon: \\
16.12.2019 \\
Kabul: \\
21.12 .2019 \\
\\
Sorumlu Yazar: \\
Inci Turan \\
dr.incituran@gmail.com \\
\hline Anahtar Kelimeler: \\
Çevresel zenginleştirme, Karotid \\
arter oklüzyonu, Oksidatif stres, \\
Retina
\end{tabular}

Ö Z

Amaç: Çevresel zenginleştirmenin iskemiye veya travmaya bağlı gelişen patolojilerde hasarı azalttığı çeşitli çalışmalar tarafından gösterilmiştir. Bilateral karotid arter oklüzyonu (2VO) kapiller damar hasarına, özellikle optik sinir ve retinada dejenerasyona neden olmaktadır. Bu çalışmanın amacı çevresel zenginleştirmenin 2VO yapılan sıçanlarda retinal oksidatif stres ve C vitamini üzerine etkisini incelemektir.

Gereç ve Yöntemler: Çalışmada 24 adet Wistar albino erkek sıçan (250-300 g) kullanıldı. Denekler rasgele olmak üzere kontrol, $2 \mathrm{VO}+$ standart çevre $(\mathrm{N})$, ve $2 \mathrm{VO}+$ zenginleştirilmiş çevre (EE) olarak 3 gruba ayrıldı. 2VO kalıcı bilateral karotid arter oklüzyonu ile gerçekleştirildi ve EE 4 hafta boyunca uygulandı. Deney sonunda göz dokularında malondialdehid (MDA), indirgenmiş glutatyon (GSH) ve askorbik asit düzeyleri ölçüldü.

Bulgular: Çevresel zenginleştirme standart çevre grubu ile karşılaştırıldığında retinal MDA seviyelerini azalttı. 2VO göz dokusunda, kontrol grubu ile karşılaştırıldığında GSH düzeylerini ve $\mathrm{C}$ vitamini miktarını düşürdü. $(\mathrm{p}<0.05)$. EE standart çevre grubuna kıyasla GSH seviyelerini düzeltti. Fakat EE'nin retinal askorbik asit düzeylerini etkilemediği gözlendi ( $\mathrm{p}>0.05)$.

Sonuç: Bu çalışmanın sonuçları çevresel zenginleştirmenin 2VO ile retinada oluşan oksidatif stresi azaltmada etkili olabileceğini göstermektedir. 


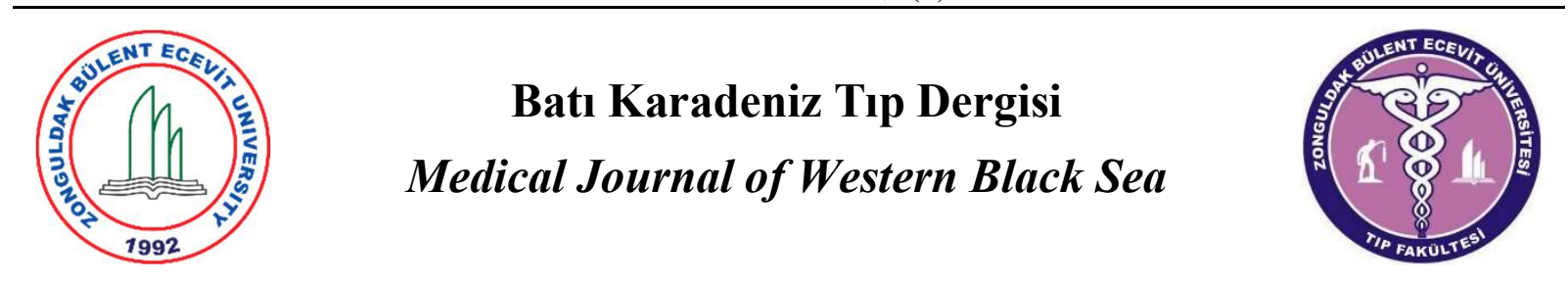

Research Article

Doi: 10.29058/mjwbs.2019.3.4

\section{Environmental Enrichment Attenuate Retinal Oxidative Stress Induced by Bilateral Carotid Artery Occlusion}

Incı Turan a, Osman Cengıl b, Büşra Onar ${ }^{b}$, Birgül Altuğ ${ }^{b}$, Hale Sayan Ozacmak ${ }^{\text {a }}$, Veysel Haktan Ozacmak ${ }^{a}$

${ }^{a}$ Zonguldak Bulent Ecevit University School of Medicine, Physiology Department, Zonguldak, Turkey.

${ }^{b}$ Zonguldak Bulent Ecevit University Health Science Instute Physiology Department, Zonguldak, Turkey.

A R T I C L E

\begin{tabular}{l} 
I N F O R M A T I O N \\
\hline Date of Submission \\
22.11.2019 \\
Revision: \\
16.12.2019 \\
Accepted: \\
21.12.2019
\end{tabular}

Correspondence Author:

Inci Turan

dr.incituran@gmail.com

Key Words:

Environmental enrichment,

Carotid artery occlusion,

Oxidative stress, Retina

\section{A B S T R A C T}

Aim: Various studies have shown that environmental enrichment reduces the tissue damage in ischemia or trauma-related pathologies. Bilateral carotid artery occlusion (2VO) leads to capillary vessel damage, especially degeneration of the optic nerve and retina. The aim of this study was to investigate the effect of environmental enrichment on retinal oxidative stress and vitamin $\mathrm{C}$ in $2 \mathrm{VO}$ rats. Material and Methods: 24 Wistar Albino male rats (250-300 g) were used in the study. The rats were randomly separated into 3 groups as the control, 2VO+ standart environment (SE), 2VO+ environmental enrichment (EE). $2 \mathrm{VO}$ was induced by permanent bilateral carotid artery occlusion and EE was performed for 4 weeks. At the end of this period malondialdehyde (MDA), reduced glutathione (GSH) and ascorbic acid levels were measured in eye tissues.

Results: Environmental enrichment reduced retinal MDA levels compared with the standard environmental group. 2VO decreased GSH levels and vitamin C compared with control group in eye tissues. EE ameliorated GSH levels compared to standard environmental group. However, EE did not affect retinal ascorbic acid levels.

Conclusion: The results of this study show that environmental enrichment may be effective in reducing $2 \mathrm{VO}$ induced oxidative stress in the retina. 


\section{Giriş}

Vasküler demans (VD), hemorajik veya iskemik serebrovasküler hastalığa bağlı kognitif bozukluk ile karakterize klinik bir durumdur. Demans türleri arasında en sık gözlenen ikinci türdür. VD'ın kesin nedeni tam olarak anlaşılamamasına rağmen, çalışmalar VD gelişiminin kronik serebral hipoperfüzyon $(\mathrm{CCH})$ ile yakından ilişkili olduğunu göstermiştir (1). Karotid arterlerin kalıcı bilateral oklüzyonu (2VO), hipokampal nöronların ilerleyici kaybına, kolinerjik işlev bozukluğuna ve bilişsel bozukluğa yol açan $\mathrm{CCH}$ modelidir. 2VO, göz kan akımında orta dereceli bir azalmaya yol açar, böylece retinay1 ve optik siniri etkiler $(2,3)$. Dolayısıyla 2VO, vasküler defektlerle ilişkili retina dejenerasyonunun mekanizmalarını ve tedavisini araştırmak için yararlı bir model sağlar (2). Ayrıca karotis arter stenozu, oküler iskemik sendroma neden olabilir (4).

İskemi, diyabetik retinopati, glokom ve yaşla ilişkili maküler dejenerasyon gibi birçok retinal hastalığın patofizyolojisini belirleyen başlıca faktörlerden biridir. Retinal hipoksi ve iskemi, hücre ölümü ile sonuçlanan bir dizi tetikleyici reaksiyon başlatarak nöronal enerji metabolizmasını etkiler (5). Enerji metabolizmalarının bozulması serbest oksijen radikallerinin üretiminde artışa neden olarak oksidatif stresi tetikler. Böylece retinal iskemi oksidatif stresi içeren kompleks mekanizmalarla retinanın bütün tabakalarında dejenerasyona yol açar ve retinal hücre sayılarında azalmaya neden olur. Ancak 2VO sırasında gelişen retinal hasarın patofizyolojisi hala tam olarak anlaşılamamıştır. Çevresel zenginleştirmenin (EE) sinir sisteminin gelişimini etkilediği gibi görsel sistemi de etkilediği bildirilmiştir. EE'nin iskemik ve travmatik hasarlara bağlı lezyonları azalttığı çeşitli çalışmalar tarafından kanıtlanmıştır $(6,7)$. Sıçanlarda erken postnatal ve hatta prenatal zenginleştirmenin retinal gelişimi hızlandırdığg gösterilmiştir. Son zamanlarda çevresel zenginleştirmenin retinanın neonatal lezyonunda koruyucu bir etkisi olduğu gösterilmiştir (8). Bu çalışmanın amacı çevresel zenginleştirmenin $2 \mathrm{VO}$ ile oluşturulan iskemik oküler hasarda oksidatif stres üzerine ve askorbik asit düzeylerine olan etkisini incelemektir.

\section{Gereç ve Yöntemler}

Deneylerde Zonguldak Bülent Ecevit Üniversitesi Deney Hayvanları Araştırma ve Uygulama Merkezinden (etik kurul no:2015-1301/07) elde edilen 250-300 gr ağırlığındaki 10 haftalık erkek Wistar Albino sıçanlar kullanıldı. 24 adet sıçan tartıldı ve rastgele üç gruba ayrıldı:

(1) Kontrol standart çevre ( $\mathrm{N}$ ), $\mathrm{n}=8$; Standart kafeslerde yaşatılan grup,

(2) $2 \mathrm{VO}$ cerrahi + standart çevre $(2 \mathrm{VO}+\mathrm{N}), \mathrm{n}=8$; Cerrahi prosedür uygulanıp, standart kafeslerde yaşatılan grup,

(3) $2 \mathrm{VO}$ cerrahi + çevresel zenginleştirme $(2 \mathrm{VO}+$ EE), $\mathrm{n}=8$. Cerrahi prosedür uygulanıp zenginleştirilmiş çevrede yaşatılan grup.

\section{VO Hayvan Modeli}

Cerrahi işlem uygulanacak grupların 1 (bir) gün öncesinden gıda ve su tüketimi kısıtlandı. Sıçanlara $70 \mathrm{mg} / \mathrm{kg}$ ketamin $\mathrm{HCl}$ ve $10 \mathrm{mg} / \mathrm{kg}$ Ksilazin HCL intraperitonal enjeksiyonu ile genel anestezi uygulandı. Aseptik hazırlıktan sonra boynun sağ tarafina $2 \mathrm{~cm}$ 'lik bir insizyon yapıldı ve kas ile fasya tabakaları disseke edilerek internal karotid arterlere ulaşıldı. İnternal karotid arterlere komşu dokular özellikle vagus siniri dikkatlice disseke edildi ve internal karotid arter steril 3.0 ipek iplikle kalıcı olarak bağlandı. Operasyon alanı kapatılarak gerekli pansumanlar yapıldı. Hayvanların ölüm riskini azaltmak için önce sağ taraf karotid arter, 1 (bir) hafta sonra ise sol taraf karotid arter kalıcı olarak oklüze edildi (9).

\section{Çevresel Zenginleştirme}

Zenginleştirilmiş çevre için sıçan, oyuncaklar, farklı renk ve şekillerde tüneller, koşu bantları ve ahşap veya metal merdivenler ve platformlar gibi nesneleri içeren özel olarak tasarlanmış kafes $(90 \mathrm{~cm}$ x $75 \mathrm{~cm} \mathrm{x} 45 \mathrm{~cm}$ yüksek) içinde 4 (dört) hafta boyunca tutuldu (10). Nesneler günlük olarak değiştirildi. (N) grupları standart laboratuar kafesinde ek herhangi bir nesne içermeden tutuldu (Resim 1).

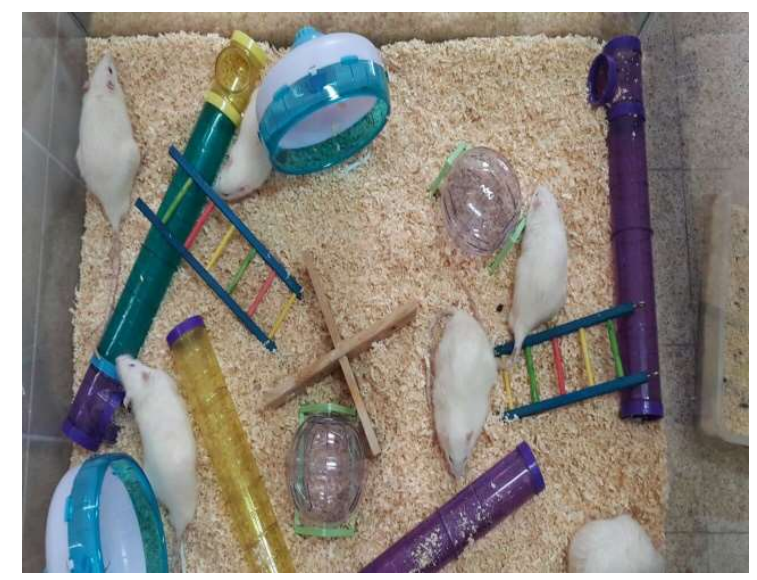

Resim 1. Zenginleştirilmiş çevre kafesi 
Hayvanlar 1 ay boyunca standart kafes veya çevresel zenginleştirme kafeslerinde tutuldular. Deney sonunda hayvanlar yüksek doz anestezi ile sakrifiye edilerek göz dokuları çıkarıldı ve analizlerin yapılacağı güne kadar -80 C de bekletildi.

\section{MDA Tayini}

Lipid peroksidasyonunun son ürünü olan ve bir indikatör olarak kullanılan MDA seviyesi Casini ve arkadaşlarının metodu esas alınarak çalışıldı (11). Analizler için -80 derecede saklanan göz doku örneklerinin buz içinde çözünmesi beklendi. Ardından dokular tartıldı. Tartılan dokunun 1 gramına $9 \mathrm{ml}$ olacak şekilde soğuk \%10’luk triklorasetik asit eklendi ve mekanik homojenizatörde homojenizasyon sağlandi. Homojenat 15 dakika santrifüj edilip $\left(18-20{ }^{\circ} \mathrm{C}\right.$ 'de $3000 \mathrm{~g}$ 'de) elde edilen $1,5 \mathrm{ml}$ süpernatan mikrosantrifüj tüplerinde 8 dakika daha santrifüj edildi (18-20 ${ }^{\circ} \mathrm{C}$ 'de $3000 \mathrm{~g}$ 'de). Ortaya çıkan $750 \mu \mathrm{l}$ süpernatan üzerine \%1'lik butilhidroksi toluenden (BHT, Sigma Chemical Co.,St. Louis, MO, USA) 10 $\mu 1$ eklendi. Üzerine $750 \mu 1 \% 0,67$ 'lik tiyobarbitürik asit (TBA, Sigma Chemical Co.,St. Louis, MO, USA) eklendi. Karışım 15 dakika kaynatıldı. Elde edilen örnekler $535 \mathrm{~nm}$ 'de spektrofotometrik olarak okundu.

\section{GSH Tayini}

Major endojen antioksidan olan GSH seviyeleri Aykac ve arkadaşlarının metoduna göre çalışıldı (12). MDA ölçümünde kullanılan yöntemle elde edilen $250 \mu \mathrm{l}$ örnek süpernatana $1 \mathrm{ml} \quad 0,3 \mathrm{M}$ Na2HPO4 (Sigma Chemical Co.,St. Louis, MO, USA) eklendi. Üzerine $125 \mu \mathrm{l}$ ditiobisnitrobenzoat (Sigma Chemical Co.,St. Louis, MO, USA) eklendi. Örnekler vorteksleme sonrası 412 nm'de spektrofotometrede okundu.

\section{Askorbik Asit (AA) Tayini}

Askorbik asit seviyesi Roe ve Keuther'in metodu esas alınarak çalışıldı (13). -80 derecede saklanan göz doku örneklerinin buz içinde çözünmesi beklendi ve dokular tartıld1. Tartılan dokunun 1 gramına $9 \mathrm{ml}$ olacak şekilde soğuk perklorik asit ve $0.1 \mathrm{mg}$ etilendiamintetraasetik (PCA / EDTA) eklendi ve mekanik homojenizatörde homojenizasyon sağlandı. Homojenat 3 dakika santrifüj edildi ( $4{ }^{\circ} \mathrm{C}$ 'de $15000 \mathrm{~g}$ 'de) ve süpernatan elde edildi. Bir santrifüj tüpüne ortaya çıkan $200 \mu 1$ süpernatan, $200 \mu \mathrm{l}$ standart ve $50 \mu \mathrm{l}$ renk reaktifi (\% 0.6 bakır sülfat, $\% \quad 5$ tiyoüre ve 2,4dinitrofenilhidrazin, 1: 1: 20) eklendi. Örnekler 37 ${ }^{\circ} \mathrm{C}$ 'de 3 saat su banyosunda tutulduktan sonra 0 ${ }^{\circ}$ C'ye soğutuldu ve $300 \mu 1 \%$ 65'lik sülfürik asid eklendi. Elde edilen örnekler 515 nm'de spektrofotometrik olarak okundu.

\section{Istatistiksel Analiz}

İstatistiksel analizler SPSS 22.0 (SPSS Inc., Chicago, IL,USA) programı kullanılarak yapıldı. Değerler medyan (min-max) olarak ifade edildi. Gruplar arasındaki farklılık ve alt grupların karşılaştırılması için Kruskal-Wallis post hoc Dunn testi kullanıldı. Tüm değerlendirmeler için $\mathrm{p}<0.05$ değeri anlamlı kabul edildi.

\section{Bulgular}

\section{MDA sonuçları}

Göz dokularında 2VO sonrasında lipid peroksidasyon göstergesi olan MDA düzeyleri artmış ancak istatistiksel olarak anlamsız bulundu. Çevresel zenginleştirme (EE) yapılan grup standart çevre koşullarıyla kıyaslandığında MDA düzeylerinin azaldığı tespit edildi (Tablo 1)(Şekil $1)(\mathrm{p}<0.05)$.

Tablo 1. Çevresel Zenginleştirmenin Retinal Oksidatif Strese Etkisi

\begin{tabular}{|c|c|c|c|c|}
\hline & $\begin{array}{c}N \\
(n=8)\end{array}$ & $\begin{array}{c}2 \mathrm{VO}+\mathrm{N} \\
(\mathrm{n}=8)\end{array}$ & $\begin{array}{c}2 \mathrm{VO}+\mathrm{EE} \\
\quad(\mathrm{n}=8)\end{array}$ & $\mathbf{p}$ \\
\hline MDA & $45(43-49)$ & $52(47-57)$ & $36(27-41)^{\&}$ & 0.001 \\
\hline GSH & $7.5(6-10)$ & $4.5(3-5) *$ & $8(6-11)^{\&}$ & 0.001 \\
\hline $\mathbf{A A}$ & $2.27(1.21-3.41)$ & $1.31(1.21-1.36)$ * & $1.38(0.98-1.41) *$ & 0.006 \\
\hline
\end{tabular}

Değerler ortanca (min-max) olarak verilmiştir. * N'e göre, \& 2VO+N göre $(\mathrm{p}<0,05)$. MDA: Malondihaldehid (nmol/gr). GSH: İndirgenmiş glutatyon ( $\mu \mathrm{mol} / \mathrm{gr})$. AA: Askorbik asit (nmol/gr). 


\section{GSH sonuçları}

GSH düzeyleri ölçüldüğünde karotid arter oklüzyonu GSH düzeyini kontrol grubuna göre önemli ölçüde azalttı. Çevresel zenginleştirmenin bu azalmayı anlamlı olarak düzelttiği ve kontrol seviyelerine yükselttiği görüldü (Tablo 1)(Şekil 2).

\section{Askorbik asit sonuçlart}

Bilateral karotid arter oklüzyonu göz dokusunda askorbik asit düzeylerini anlamlı olarak azalttı. Çevresel zenginleştirmenin ise askorbik asit düzeylerine herhangi bir etkisinin olmadığı tespit edildi (Tablo 1)(Şekil 3).

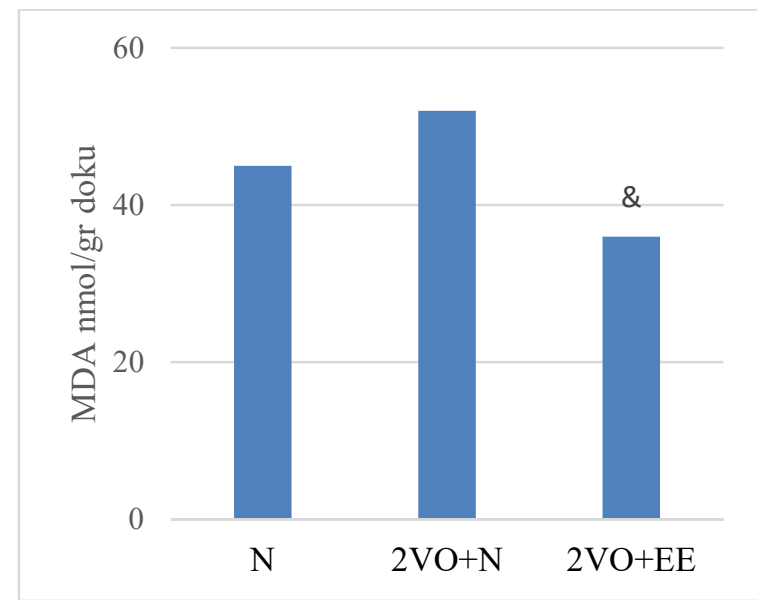

Şekil 1: Göz dokusu MDA düzeyleri, değerler ortanca şeklinde verilmiştir. \& $2 \mathrm{VO}+\mathrm{N}$ grubuna göre $(\mathrm{p}<0.05)$

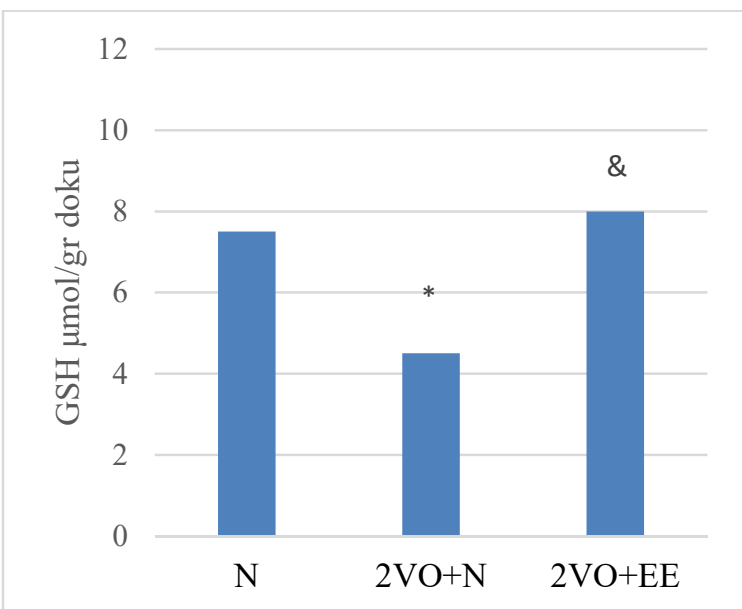

Şekil 2: Göz dokusu GSH düzeyleri, değerler ortanca şeklinde verilmiştir. * N'e göre. \& $2 \mathrm{VO}+\mathrm{N}$ grubuna göre $(\mathrm{p}<0.05)$.

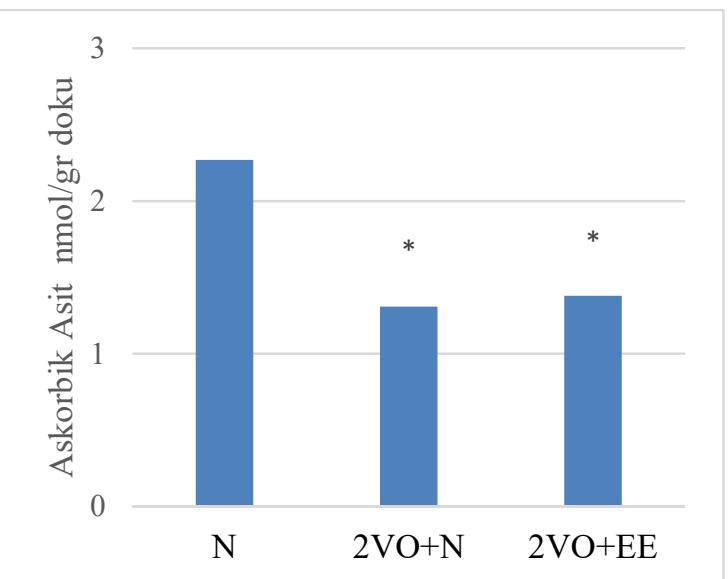

Şekil 3: Göz dokusu askorbik asit düzeyleri, değerler ortanca şeklinde verilmiştir. * N'e göre $(\mathrm{p}<0.05)$.

\section{Tartışma}

Çalışmadan elde edilen sonuçlar, çevresel zenginleştirmenin karotid arter oklüzyonu ile oluşan oküler hasarı, oksidatif stresi azaltarak ve antioksidan molekülleri arttırarak hafifletebileceğini göstermektedir. EE karotid arter oklüzyonu ile azalan askorbik asit düzeylerinde ise herhangi bir değişiklik yaratmamıştır. Dolayısıyla çevresel değişikliklerin retinal hasarlarda belirleyici faktörlerden biri olduğu önerilebilir.

Çevresel zenginleştirme, nöronal yaralanmaların etkilerini azaltma potansiyeline sahip popüler bir stratejidir. Zenginleştirilmiş ortamların toksik, iskemik ve travmatik hasarlarda koruyucu olduğu gösterilmiştir ve retina üzerinde de koruyucu etkileri olduğu çeşitli çalışmalarda kanıtlanmıştır $(8,14,15)$. $\mathrm{Bu}$ nedenle, çevresel zenginleştirme retinal iskemik lezyonlara karşı iyi bir koruyucu uygulama olarak görülür (8)

Çevresel zenginleştirme, sosyal etkileşim, fiziksel egzersiz ve sürekli öğrenme görevlerinin kombinasyonunu içeren bir uyarı artışıdır. Çevresel zenginleştirmenin koruyucu etkilerinin altında yatan mekanizmalar birçok yolağa bağlanmıştır. Özellikle nöronlarda dendrit sayılarını, dallanma ve spinleri arttırdığı, glial hücre sayılarında artışa neden olduğu, inflamasyonu azalttığı, mikrogliyal fagositozu arttırdığı ve hipokampüste anjiogenez ve nörogenezde etkili olduğu gösterilmiştir $(16,17)$. Doğumdan itibaren EE'ye maruz bırakılan farelerin, standart çevre koşullarına sahip kontrollerle karşılaştırıldığında görme keskinliğinin arttığ ve görsel sistemin performansının, görsel ortamın zenginliğinden büyük ölçüde etkilendiği gösterilmiştir (18). Ayrıca EE oksitleyici süreçleri 
zayıflatır ve Alzheimer hastalığında antioksidan savunma mekanizmalarını tetikler (16).

Çalışmalar 2VO sırasında, retinadaki kan akışının, beyin kan akışına göre daha ciddi şekilde azaldığını göstermişlerdir ve bu durumun hipoperfüzyon sırasında göz içi basıncının artmasından kaynaklandığını ileri sürmüşlerdir (3). Bilateral karotid arter oklüzyonu sırasında alınan elektroretinogram kayıtlarında fotoreseptör, bipolar ve Müller hücre düzeylerinin etkilendiği ve $b$ dalgalarının azaldığı tespit edilmiştir. Bilateral karotid arter oklüzyonu sonrasında retinal gangliyon hücrelerinin ve fotoreseptörlerin hasarlandığ bildirilmiştir (3). Ayrıca kronik serebral hipoperfüzyonun yol açtığı retinal iskemi, hücre ölümü ile sonuçlanabilen bir dizi tetikleyici reaksiyonu başlatır. İlk olarak nöronal enerji metabolizması bozulur (5). Mitokondriyal enerji metabolizmasının bozulması serbest oksijen radikallerinin oluşumu ve oksidatif stresin meydana gelmesinde temel mekanizmadır (19). Serbest oksijen radikallerinin birikmesi DNA ve lipid peroksidasyonuna neden olarak hücrelerin apoptozis veya ölümüne neden olmaktadır. MDA lipid peroksidasyonunun son ürünüdür ve bir belirteç olarak kullanılmaktadır (19). Bu çalışmada 2VO yapılan sıçanların göz dokularında oksidatif stresin bir göstergesi olan MDA düzeyleri çevresel zenginleştirme ile azalmıştır. Benzer şekilde $2 \mathrm{VO}$ uygulanan ratlarda çevresel zenginleştirmenin beyin dokusunda lipid peroksidasyon seviyesinde azalma ve antioksidan enzim miktarlarında artmaya neden olduğu başka çalışmalarda gösterilmiştir (16). Çalışmamız bu yönüyle literatürü desteklemektedir. Sun ve arkadaşları (2016) posttravmatik beyin dokusunda çevresel zenginleştirmenin beyin dokusunda oksidatif stresi ve NADPH enzim düzeylerini azalttığını göstermişlerdir (20). Dorfman ve arkadaşları çevresel zenginleştirmenin retinal iskemide glutamat toksisitesinde azalmaya neden olduğunu bildirmişlerdir (5) .

İskemi ile tetiklenen oksidatif stresin yaratacağ hasar antioksidan mekanizmaların devreye girmesiyle önlenmeye çalışılır. En önemli endojen antioksidan enzimlerden biri olan GSH'ın iskemi ile azaldığı birçok çalışmada gösterilmiştir $(21,22)$. Yapılan yeni bir çalışma toluene maruz kalan farelerde hipokampüs ve prefrontal korteks bölgelerinde azalan GSH seviyelerinin çevresel zenginleştirme ile normal seviyelere yükseldiğini göstermiştir (23). EE'nin yalnızca GSH seviyelerinde değil süperoksit dismutaz ve glutatyon S-transferaz gibi diğer antioksidan enzim düzeylerini arttırdığıda gösterilmiştir $(23,24)$. Bizde çalışmamızda $2 \mathrm{VO}$ ile retinada azalan GSH seviyelerinin zenginleştirilmiş çevre ile kontrol düzeylerine yükseldiğini gözlemledik. Bu yönüyle EE antioksidan sisteme katkı sağlıyor ve olası yararlı etkilerini antioksidan etkisi ile ortaya çıkarıyor olabilir.

Askorbik asit beyin dokusunda ve nöronlarda bulunan ve suda çözünen önemli antioksidan moleküllerdendir. Fizyolojik koşullar altında askorbik asit serbest oksijen radikallerine karş1 savunmada diğer hücresel antioksidan moleküller ile birlikte çalışır (25). Askorbik asit merkezi sinir sisteminin sinyal yolaklarında önemli roller üstlenmektedir. Özellikle retinada askorbik asit için yüksek afiniteli bir taşıma sistemi tanımlanmıştır (26). İnme gibi beyin iskemisi yaşanan durumlarda askorbik asit seviyesinin azaldığı bildirilmektedir (27). Çalışmamızda 2VO uygulaması ile retinal askorbik asit düzeyleri önemli miktarda azalmıştır. Azalan askorbik asidin antioksidan dengeyi negatif etkilediğini düşünürsek bu durum $2 \mathrm{VO}$ sırasında oluşan retinal hasarı arttırıyor olabilir. Çevresel zenginleştirmenin ise azalan askorbik asit düzeylerinde iyileştirici herhangi bir etkisi saptanmamıştır.

$\mathrm{Bu}$ çalışma sonucunda çevresel zenginleştirmenin göz dokusunda lipid peroksidasyon seviyesinde azalma ve indirgenmiş glutatyon enzim seviyelerinde artma sağlayarak 2VO ile oluşturulan retinal kronik iskemik hasarı azaltan yararlı etkisi görülmüştür. $\mathrm{Bu}$ sonuçlar retinal dejenerasyon yaratan patolojilerde çevresel zenginleştirmenin yeni bir tedavi yaklaşımı olabileceğini göstermektedir. Altta yatan patofizyolojik mekanizmaların aydınlatılması için yapılacak ayrıntılı çalışmalara ihtiyaç bulunmaktadır.

\section{Kaynaklar}

1. Yao P, Li Y, Yang Y, Yu S, Chen Y. Triptolide Improves Cognitive Dysfunction in Rats with Vascular Dementia by Activating the SIRT1/PGC$1 \alpha$ Signaling Pathway. Neurochem Res 2019; 44(8): 1977-1985.

2. Sivilia S, Giuliani A, Fernández M, Turba ME, Forni M, Massella A, De Sordi N, Giardino L, Calzà L. Intravitreal NGF administration counteracts retina degeneration after permanent carotid artery occlusion in rat. BMC Neurosci 2009; 10: 52.

3. Yamamoto H, Schmidt-Kastner R, Hamasaki DI, Yamamoto H, Parel JM. Complex 
neurodegeneration in retina following moderate ischemia induced by bilateral common carotid artery occlusion in Wistar rats. Exp Eye Res 2006; 82(5): 767-79.

4. Mester L, Szabo A, Atlasz T, Szabadfi K, Reglodi D, Kiss P, Racz B, Tamas A, Gallyas F Jr, Sumegi B, Hocsak E, Gabriel R, Kovacs K. Protection against chronic hypoperfusion-induced retinal neurodegeneration by PARP inhibition via activation of PI-3-kinase Akt pathway and suppression of JNK and p38 MAP kinases. Neurotox Res 2009; 16(1): 68-76.

5. Dorfman D, Fernandez DC, Chianelli M, Miranda M, Aranda ML, Rosenstein RE. Post-ischemic environmental enrichment protects the retina from ischemic damage in adult rats. Exp Neurol 2013; 240: $146-56$.

6. Xiong S, Xu Y, Ma M, Wang H, Wei F, Gu Q, Xu X. Neuroprotective effects of a novel peptide, FK18, under oxygen-glucose deprivation in SH-SY5Y cells and retinal ischemia in rats via the Akt pathway. Neurochem Int 2017; 108: 78-90.

7. Wang CJ, Wu Y, Zhang Q, Yu KW, Wang YY. An enriched environment promotes synaptic plasticity and cognitive recovery after permanent middle cerebral artery occlusion in mice. Neural Regen Res 2019; 14(3): 462-469.

8. Kiss P, Szabadfi K, Horvath G, Tamas A, Farkas J, Gabriel R, Reglodi D Gender-dependent effects of enriched environment and social isolation in ischemic retinal lesion in adult rats. Int $\mathrm{J}$ Mol Sci 2013; 14(8): 16111-23

9. Yang Y, Zhang J, Xiong L, Deng M, Wang J, Xin J, Liu H. Cognitive Improvement Induced by Environment Enrichment in Chronic Cerebral Hypoperfusion Rats: a Result of Upregulated Endogenous Neuroprotection? J Mol Neurosci 2015; 56(2): 278-89.

10. Zhu H, Zhang J, Sun H, Zhang L, Liu H, Zeng $\mathrm{X}$, Yang Y, Yao Z. An enriched environment reverses the synaptic plasticity deficit induced by chronic cerebral hypoperfusion. Neurosci Lett 2011; 502(2): 71-5.

11. Casini A, Ferrali M, Pampella A, Maellaro E, Combarti M. Lipid peroxidation and cellular damage in extrahepatic tissues of bromobenzene in toxicated mice. Am J Pathol 1989; 123: 520-31.
12. Aykac G, Uysal M, Yalan AS, Kocak Toker N, Sivas A, Oz H. The effects of chronic ethanol injection on hepatic lipid peroxide, glutathione, glutathione peroxidase and glutathione transferase in rats. Toxicology 1985; 36: 71-6.

13. Berger J, Shepard D, Morrow F, Taylor A. Relationship between dietary intake and tissue levels of reduced and total vitamin $\mathrm{C}$ in the nonscorbutic guineapig. J Nutr 1989; 119: 734-40

14. Schneider JS, Lee MH, Anderson DW, Zuck L, Lidsky TI. Enriched environment during development is protective against lead-induced neurotoxicity. Brain Res 2001; 896(1-2): 48-55.

15. Zhu H, Zhang J, Sun H, Zhang L, Liu H, Zeng $\mathrm{X}$, Yang Y, Yao Z. An enriched environment reverses the synaptic plasticity deficit induced by chronic cerebral hypoperfusion. Neurosci. Lett 2011; 502: 71-75.

16. Cechetti F, Worm PV, Lovatel G, Moysés F, Siqueira IR, Netto CA. Environmental enrichment prevents behavioral deficits and oxidative stress caused by chronic cerebral hypoperfusion in the rat. Behav Brain Res 2016; 312: 84-92.

17. Herring A, Yasin H, Ambrée O, Sachser N, Paulus W, Keyvani K. Environmental enrichment counteracts Alzheimer's neurovascular dysfunction in TgCRND8 mice. Brain Pathol 2008; 18(1): 32-9.

18. Prusky GT, Reidel C, Douglas RM. Environmental enrichment from birth enhances visual acuity but not place learning in mice. Behav Brain Res 2000; 114(1-2): 11-5.

19. Liu L, Sun Q, Wang R, Chen Z, Wu J, Xia F, Fan $X Q$. Methane attenuates retinal ischemia/reperfusion injury via anti-oxidative and anti-apoptotic pathways. Brain Res 2016; 1646: 327-333.

20. Sun XR, Zhang H, Zhao HT, Ji MH, Li HH, Wu J, Li KY, Yang JJ. Amelioration of oxidative stressinduced phenotype loss of parvalbumin interneurons might contribute to the beneficial effects of environmental enrichment in a rat model of posttraumatic stress disorder. Neurochem Res. 2007; 32(8): 1314-21.

21. Turan I, Sayan Ozacmak H, Ozacmak VH, Barut F, Ozacmak ID. The effects of S-nitrosoglutathione on intestinal ischemia reperfusion injury and acute lung injury in rats: Roles of oxidative stress and NF$\kappa$ B. Tissue Cell 2018; 52: 35-41. 
22. Polat N, Ozer MA, Parlakpinar H, Vardi N, Aksungur Z, Ozhan O, Yildiz A, Turkoz Y. Effects of molsidomine on retinal ischemia/reperfusion injury in rabbits. Biotech Histochem 2018; 93(3): 188-197.

23. Montes S, Yee-Rios Y, Páez-Martínez N. Environmental enrichment restores oxidative balance in animals chronically exposed to toluene: Comparison with melatonin. Brain Res Bull 2019; 144: 58-67.

24. Kang H, Choi DH, Kim SK, Lee J, Kim YJ. Alteration of Energy Metabolism and Antioxidative Processing in the Hippocampus of Rats Reared in Long-Term Environmental Enrichment. Dev Neurosci 2016; 38(3): 186-194.

25. Ozacmak VH, Sayan H, Cetin A, AkyildizIgdem A. AT1 receptor blocker candesartan-induced attenuation of brain injury of rats subjected to chronic cerebral hypoperfusion. Neurochem Res. 2007 Aug;32(8):1314-21.

26. Domith I, Socodato R, Portugal CC, Munis AF, Duarte-Silva AT, Paes-de-Carvalho R. Vitamin C modulates glutamate transport and NMDA receptor function in the retina. J Neurochem 2018; 144(4): 408-420.

27. Sánchez-Moreno C, Dashe JF, Scott T, Thaler D, Folstein MF, Martin A. Decreased levels of plasma vitamin $\mathrm{C}$ and increased concentrations of inflammatory and oxidative stress markers after stroke. Stroke 2004; 35(1): 163-8. 